\title{
A CRISE DA SOBERANIA DO ESTADO MODERNO NO CONTEXTO DA PANDEMIA DA COVID-19: REFLEXÕES NO MEIO DO CAMINHO
}

\author{
Julia Borges da Costa Abdalla ${ }^{1}$ \\ Elve Miguel Cenci ${ }^{2}$
}

\begin{abstract}
Resumo
Este artigo objetiva analisar os reflexos e consequências da pandemia do Covid-19 na discussão da crise da soberania do Estado Moderno. Neste sentido, analisa-se o caminho do conceito de soberania ao longo da história e as características da crise no Estado Moderno. Em seguida, observa-se a atuação estatal do Brasil frente às orientações da Organização Mundial da Saúde, e como esta reacendeu a discussão acerca da necessidade - ou não - de fortalecimento do agente estatal, bem como a urgência em realização do "constitucionalismo global" proposto por Luigi Ferrajoli. Adota-se uma postura metodológica indutiva como caminho metodológico da investigação.
\end{abstract}

Palavras-chave: Soberania Estatal; Estado Moderno; Crise; Pandemia; Constitucionalismo Global.

\section{THE CRISIS OF THE SOVEREIGN STATE IN THE CONTEXT OF COVID-19 PANDEMIC: REFLECTIONS IN THE MIDDLE OF THE WAY}

\begin{abstract}
This article aims to analyze the reflexes and consequences of the Covid-19 pandemic in the discussion of the sovereignty crisis of the Modern State. In this sense, we analyze the path of the concept of sovereignty throughout history and the characteristics of the crisis in the Modern State. Then, it is possible to observe the state action of Brazil in face of the guidelines of the World Health Organization, and how it rekindled the discussion about the need - or not - to strengthen the state agent, as well as the urgency in carrying out "global constitutionalism" proposed by Luigi Ferrajoli. An inductive methodological stance is adopted as the methodological path of the investigation.
\end{abstract}

Key-words: State Sovereignty; Modern State; Crisis; Pandemic; Global Constitutionalism.

\section{INTRODUÇÃO}

A pandemia provocada pelo Sars-CoV-2, o novo coronavírus, que assola o planeta em 2020 tem sido fonte de grande preocupação para todos, em especial, em relação aos seus

\footnotetext{
${ }^{1}$ Mestranda em Direito Negocial pela Universidade Estadual de Londrina (UEL), 2020-2022. Especialista em Direito Empresarial pela Fundação Getúlio Vargas (FGV). Advogada;

2 Doutor em Filosofia pela Universidade Federal do Rio de Janeiro-UFRJ/RJ. Professor e Coordenador do Programa de Mestrado em Direito Negocial na Universidade Estadual de Londrina (UEL).
} 
efeitos econômicos. Para muitos, estamos diante de um acontecimento único que, ao mesmo tempo que destrói algo existente, dá início a algo novo, uma espécie de supernova ${ }^{3}$. O "novo normal", como assim popularmente conhecido o período pós pandemia, suscita novas inquietações e indagações dentro dos países, sobre temas adormecidos.

Todas as situações vivenciadas no ano de 2020 trouxeram à tona a discussão acerca da crise da soberania estatal o que, de certa maneira, não causou estranhamento. As posições adotadas pelos países em meio as recomendações da Organização Mundial da Saúde (OMS) e a distinção entre as condutas perpetradas por vários Estados, novamente acendeu o debate acerca da necessidade - ou não - de fortalecimento do Estado, em um mundo multilateral.

O debate acerca da crise da soberania ganhou um novo capítulo. O mundo está assistindo o aumento do número de mortes causadas pela pandemia do novo coronavírus e eminente recessão econômica assombrando muitos países. Todavia, a adoção desenfreada de medidas contrárias as orientações da OMS além do pânico, em muitas situações, trouxeram novamente os questionamentos acerca dos limites da atuação estatal, especialmente frente aos organismos internacionais.

Desta feita, o artigo destaca a discussão da Crise da Soberania do Estado Moderno inserida no contexto de pandemia e os efeitos, consequências e perspectivas, especialmente no que tange ao "constitucionalismo global" proposto por Luigi Ferrajoli. Para tanto, o trabalho estrutura-se em dois pontos principais.

No primeiro, discorre-se sobre a formação da soberania moderna, traçando fatos históricos e pensamentos dos principais filósofos sobre o tema, neste momento, busca entender o caminho percorrido pelo conceito de soberania e quais fatores influenciaram a mudança de perspectiva. Em seguida, observa-se a Crise do Estado com o advento da globalização e aumento da interdependência entre os Estados, com a possibilidade de novas formas de coordenação das ações para além da esfera estatal.

No segundo, é apresentado o cenário da atual pandemia do Covid-19 e analisa-se, o comportamento estatal perante as recomendações emitidas pela Organização Mundial da Saúde, para refletir se constituem caráter vinculante ou se o Estado, como ente soberano, pode se esquivar do respeito às recomendações. Para tanto, objetiva-se responder aos questionamentos com base no "constitucionalismo global" proposto por Luigi Ferrajoli,

\footnotetext{
3 "Um evento astronômico que ocorre durante os estágios finais da evolução de algumas estrelas, que é caracterizado por uma explosão muito brilhante. As ondas de choque liberadas pela explosão podem desencadear a formação de novas estrelas e até mesmo sistemas solares." (TINOCO, 2020)
} 
apresentando suas perspectivas e a realidade no plano fático. Ao final, o trabalho destaca a fragilidade humana perante a catástrofe que assola o mundo, e a necessidade de respostas globais coordenadas e homogêneas para conter o avanço de uma pandemia mundial que está ocasionando milhares de mortes no planeta.

\section{DIAGNÓSTICO DA CRISE DA SOBERANIA NO ESTADO MODERNO}

A palavra soberania em um primeiro momento nos remete à independência. Bobbio (1998, p. 1438) descreve que o conceito de soberania pode ter duas facetas: uma ampla e outra restrita. A primeira relaciona-se ao poder de mando em última instância, isto é, o poder que diferencia esta associação humana das demais, sendo um conceito intimamente ligado ao viés político. Já o conceito restritivo que aparece no final do século XVII seria a caracterização do poder estatal sujeito único e exclusivo da política.

Ainda, a importância do conceito como ponto de referência para diversos estudos é destacada por Bobbio (1998, p. 1439):

\footnotetext{
O termo Soberania se torna, assim, o ponto de referência necessário para teorias políticas e jurídicas muitas vezes bastante diferentes, de acordo com as diferentes situações históricas, bem como a base de estruturações estatais muitas vezes bastante diversas, segundo a maior ou menor resistência da herança medieval; mas é constante o esforço por conciliar o poder supremo de fato com o de direito.
}

Neste sentido, para estudo da soberania, torna-se indispensável uma análise histórica, que nos possibilite extrair e compreender os aspectos contemporâneos do tema.

Jean Bodin foi o primeiro teórico a desenvolver o conceito de soberania em suas obras "Les six livres de La République", em 1576, definindo como um "poder absoluto e perpétuo", sendo absoluto pois não estaria sujeito às ordens de ninguém, frisa-se, nem as do próprio príncipe, e perpétuo pois o exercício da soberania não poderia estar vinculado a um prazo de duração, caso contrário, perderia sua essencialidade, tornando-se mero guardião desse poder. Ainda, os limites para soberania de acordo com Bodin seriam a lei divina e a lei natural (DALLARI, 2010, p. 77).

Insta salientar que o conceito de soberania está intimamente ligado ao momento histórico em que é concebido, desta feita, para Bodin a imagem de poder estaria representada na personificação da monarquia Francesa do século XVI. Ainda, em que pese o conceito de 
soberania arbitrária conte com poucos teóricos, os seus exemplos práticos são inumeros (BOBBIO, 1998, p. 1183).

Nota-se, então, a superação do modelo feudal e formação e consolidação do modelo de Estado Absolutista, no qual, a soberania era requisito intrínseco e fundamental, uma vez que o soberano deveria estar acima de tudo e de todos.

Já em 1762, Jean Jacques Rosseau retomou o estudo da soberania em seu livro "O Contrato Social", descrevendo que a soberania era inalienável e indivisível, e que a vontade emana do povo, concluindo por transferir sua titularidade da pessoa do governante para o povo (DALLARI, 2010, p. 78).

Pensamentos como estes buscavam a despersonalização do poder e representavam a inquietação de muitos filósofos, os quais iniciaram movimentos que culminaram com a Revolução Francesa e a ruína do absolutismo na França no ano de 1790.

Para Ferrajoli, o princípio da legalidade, a divisão de poderes e os direitos fundamentais correspondem a limitações e até negações da soberania interna. Inclusive, devido a esses princípios é que a relação existente entre o Estado e povo deixou de ser no formato soberano e súditos, pois agora ambos possuíam soberania limitada (2002, p. 28). Desta feita, observa-se que o fim do Estado absolutista culminou na ruína da soberania em seu âmbito interno.

Com a assinatura dos Tratados de Paz de Westfalia e a superação do Estado Absoluto, ocorreu a transferência do poder da figura do monarca para a do povo, inaugurando-se, assim, o surgimento do Estado Moderno. Neste modelo de Estado de Direito os poderes públicos passam a ser de absolutos para funcionais, vinculando os sujeitos à observância da lei (FERRAJOLI, 2002, p. 28). Ainda, Ferrajoli classifica como uma gigantesca ruptura com o modelo estipulado pela paz de Westfalia e a afirmação de um novo “contrato social internacional” da humanidade. (2013, p. 479)

Já no âmbito externo, a soberania como independência de qualquer poder externo, revelou-se como característica essencial do Estado Moderno, desde seu início. A reafirmação da soberania em âmbito internacional resultou na proibição da interferência em âmbito interno de cada Estado, na prática, muitas das ambições pelo estabelecimento do sistema democrático almejavam também a consecução da independência nacional (CRUZ, 2007, p. 71). Este novo Estado firmado em um conceito de soberania que viria a ser reconhecido como absoluta foi, durante séculos, o sujeito exclusivo do Direito Internacional. Naquele momento, o cenário do 
Direito Internacional era composto por entes independentes entre si, que se reconheciam reciprocamente como soberanos, e por estes motivos, pautavam suas ações internas segundo seus próprios interesses (PICININ, DA SILVA, 2015, p. 134).

Assim, a ideia do Estado Moderno está intrinsicamente ligada à capacidade do poder político em garantir a obediência às leis dentro dos limites territoriais, a soberania interna, bem como, proteger as fronteiras de outros Estados e garantir a soberania externa (CENCI, 2007, p. 2). Ocorre que, essa concepção de soberania entra em crise a partir da metade do século XX. Os anseios pela reconstrução de um período de paz e de respeito por direitos mínimos ecoou na comunidade internacional no contexto pós Segunda Guerra Mundial, resultando em esforços para adoção de documentos que ressaltassem a necessidade de garantia dos direitos humanos, como a Carta da ONU e a Declaração Universal dos Direitos Humanos em 1948.

Foi com base neste marco histórico que o Direito Internacional dos Direitos Humanos começou a se desenvolver. O indivíduo passou a ser visto como um sujeito de direitos no âmbito internacional. A internacionalização dos direitos humanos foi crescente, culminando na criação de Tratados Internacionais específicos, que visavam a proteção de todos os direitos (RAMOS, 2019, p. 46).

$\mathrm{O}$ avanço no reconhecimento da personalidade e capacidade jurídicas internacionais da pessoa humana, especialmente para pleitear seus próprios direitos, foi avanço fundamental para a criação dos sistemas internacionais de proteção. Dentre estes, ressalta-se a existência dos sistemas globais e regionais, mais especialmente Corte Europeia e Corte Interamericana de Direitos Humanos.

A jurisdição obrigatória dos tribunais internacionais de direitos humanos e o direito de petição individual constituem um dos principais pilares do mecanismo de emancipação do ser humano considerando-se seu próprio Estado (TRINDADE, 2013, p. 29).

Desta maneira, o conceito anterior de soberania revelava-se inconsistente com as mudanças e instituições jurídicas que surgiam, a soberania em âmbito externo deixa de ser absoluta e passa a se subordinar ao imperativo da paz e dos direitos humanos, como observa Ferrajoli:

Por um outro lado, a consagração dos direitos humanos na Declaração de 1948 e depois nos Pactos Internacionais de 1966 atribui a esses direitos, antes apenas constitucionais, um valor supra-estatal, transformando-os de limites exclusivos 
internos em limites agora também externos ao poder do Estado. A Carta da ONU assinala, em suma, o nascimento de um novo direito internacional e o fim do velho paradigma - o modelo Vestfália - que se firmara três séculos antes com o término de outra guerra europeia dos trinta anos. (2002, p. 40)

Esta importante transição no conceito de soberania e humanização do Direito Internacional não foi apenas em sua faceta externa. No âmbito interno, as Constituições passaram a limitar as atuações estatais, de modo que estas não possam mais atentar a direitos fundamentais, os quais não são negociáveis e muito menos revogáveis.

Com o advento da globalização e aumento da conexão entre pessoas e países, muitos autores entendem que ocorre também uma necessidade de repensar a percepção de soberania. Em que pese o termo globalização seja usado para designar inumeros fenômenos, neste artigo, usa-se para entender sua influência na soberania do Estado. Para Jose Eduardo Faria (2010, p. $01)$ :

\begin{abstract}
Globalização é um conceito aberto e multiforme, que envolve problemas e processos relativos à abertura e liberalização comerciais, à integração funcional de atividades econômicas internacionalmente dispersas, à competição interestatal por capitais voláteis e ao advento de um sistema financeiro internacional sobre o qual os governos têm decrescente capacidade de controle. Nesta perspectiva, globalização é um conceito relacionado às ideias de "compressão" de tempo e espaço, de comunicação em tempo real e dissolução de fronteiras geográficas, de multilateralismo político e de policentrismo decisório.
\end{abstract}

Sobre tal contexto, cumpre destacar que para Habermas a palavra-chave que define o processo de globalização é "rede", uma vez que:

\begin{abstract}
"Rede" tornou-se a palavra-chave, e tanto faz se se trata de vias de transporte para bens e pessoas, de correntes de mercadorias, capital e dinheiro, de transmissão e processamento eletrônicos de informações ou de circulação de pessoas, técnica e natureza. Cadeias temporais comprovam as tendências globalizantes em muitas dimensões. O termo encontra igualmente aplicação na expansão intercontinental da telecomunicação, do turismo de massa ou da cultura de massa, bem como nos riscos transnacionais da técnica de ponta e do comércio de armas, nos efeitos colaterais mundiais do ecossistema explorado ou no trabalho conjunto internacional de organizações governamentais e não governamentais".
\end{abstract}

Desta maneira, a globalização não é um destino ou definição única, e sim o oposto, uma série de complicações, dilema e aporias. Para Faria: "um processo multicausal, multidimensional, multitemporal e multicêntrico, que relativiza as escalas nacionais ao 
mesmo tempo em que amplia e intensifica as relações econômicas, sociais e políticas" (FARIA, 2010 p. 42).

Destarte, com a integração das atividades e mercados econômicos, o multiculturalismo, nota-se que os Estados sucessivamente foram perdendo parte de sua soberania, na medida em que as barreiras geográficas foram superadas. A interligação entre os países faz com que os Estados possam sofrer interferências e restrições, sem que tenha ocorrido qualquer invasão em seu território. Na verdade, as formas de mitigação da soberania começam a variar e não mais nos saltam aos olhos, em seu viés literal.

Ainda neste sentido, insta esclarecer que esta interdependência entre os Estados faz com que estes passem a observar a reação da comunidade internacional na tomada de decisão, desta maneira, o desenvolvimento de organizações transnacionais leva muitos Estado a renunciarem à sua independência de ação, em favor de outros países, especialmente no caso de aliança com países de maior supremacia, em favor da própria Organização, como é o caso da União Europeia. (CRUZ, 2007, p. 25)

Assim, com a globalização vivencia-se uma "Crise do Estado", que, na prática, nada mais é do que a própria crise da soberania. A transferência de parte do poder da decisão que era do Estado para fora de seus limites geográficos. O futuro de cada país depende cada vez menos da política interna, as decisões tomadas em empresas com abrangência global ou instituições supranacionais lideram a tomada de decisões (FERRAJOLI, 2005, p. 109-110).

Neste sentido, quando se discorre sobre a integração supranacional, busca-se algo muito maior que a mera cooperação. Não é só o caso do Estado violar obrigações vinculantes, e sim mais do que isso, é a submissão do Estado ao controle de organismos supranacionais quanto ao seu cumprimento, como é o caso das Convenção Americana de Direitos Humanos, na qual o Estado transfere uma competência de fiscalização a qual pertencia anteriormente ao próprio Estado, esvaziando-se “paulatinamente” o poder deste (CRUZ, 2007, p.86).

Para Ferrajoli, a Crise do Estado Nacional hoje vivência problemas que vem tanto de cima, quanto de baixo. A transferência maciça para organizações internacionais e sedes supraestatais de grande parte de suas funções como controle da economia, defesa militar e política monetária, funções anteriormente desenvolvidas pelo Estado, representam os problemas que vem de cima, enquanto de baixo, os impulsos dos processos de desagregação interna, pelos próprios desenvolvimentos da comunicação internacional, torna precário o 
cumprimento de outras funções essenciais do Estado: a unificação nacional e a pacificação interna (2002, p. 48-49).

Ainda, ressalta-se que, em que pese a globalização tenha trazido avanços nos campos da tecnologia, comunicação, integração dos Estados e o reconhecimento da soberania compartilhada, o nível de integração não se encontra em consonância no plano fático. Sobre o tema, salienta-se:

\begin{abstract}
A ausência de um direito público internacional focado nas grandes questões globais tem levado governos e grupos nacionais ao fechamento das fronteiras, ao protecionismo econômico e a negar aos outros direitos básicos de cidadania. A globalização trouxe integração econômica, proximidade decorrente das ferramentas de comunicação e contato mais aprofundado com novos valores e culturas. Porém, o mesmo nível de integração econômica e política não aconteceu. Como destacado, apesar do emaranhado de textos legais que tornam as pessoas mais iguais, não há a correspondente igualdade de fato. Da mesma forma, as instituições políticas não avançaram para contemplar o novo mundo que se descortinou após a queda do Muro de Berlim. (CENCI, MUNIZ, 2020)
\end{abstract}

Desta feita, observa-se que o Estrado transferiu poder em relação a funções específicas para organizações e instituições com viés supranacional. O conceito de Estado que surgiu na Idade Moderna ainda perdura, entretanto, o que observa-se é a paulatina relativização da soberania que demonstra estarmos vivenciando uma Crise do Estado. A "nova soberania" descrita por Bobbio ensina que "a colaboração internacional, cada vez mais intensa, está desgastando os poderes tradicionais dos estados soberanos” (BOBBIO, 1998, p. 1187)

Para Faria (1997, p. 47), essa espécie de soberania compulsoriamente compartilhada, tem apresentado reflexos no Estado, como cita:

Essa soberania compulsoriamente partilhada, sob pena de acabar ficando à margem da economia globalizada, tem obrigado o Estado-nação a rever sua política legislativa, a reformular a estrutura de seu direito positivo e a redimensionar a jurisdição de suas instituições judiciais amplas e ambiciosas estratégias de desregulamentação, deslegalização e desconstitucionalização, implementadas paralelamente à promoção da ruptura dos monopólios públicos. [...]. Sem ter como ampliar a complexidade de seu ordenamento jurídico e de seu aparato judicial em nível equivalente de complexidade e diferenciação funcional dos diferentes sistemas sócioeconômicos, eles passam a agir pragmaticamente. Afinal, se quanto mais tentam disciplinar e intervir, menos conseguem ser eficazes, obter resultados satisfatórios, manter a coerência lógica e assegurar a organicidade de seu direito positivo, não lhes resta outro caminho para preservar sua autoridade funcional: quanto menos procurarem disciplinar e intervir, menor será o risco de acabarem desmoralizados pela inefetividade de seu instrumental regulatório e de seus mecanismos de controle. 
Desta feita, em meio ao cenário explanado, observa-se que a soberania compulsoriamente compartilhada, como definida por Faria, resultou em diferentes consequências no âmbito estatal. Todavia, com a delineação de novos cenários em 2020, muitos voltam a se questionar se a saída seria o fortalecimento do agente estatal ou a tentativa de superação das dificuldades do sistema multilateral.

\section{A PANDEMIA DA COVID-19 E SEUS REFLEXOS NA DISCUSSÃO ACERCA DA CRISE DO ESTADO MODERNO}

No ano de 2020, assistimos a Terra parar por uma pandemia. A Covid-19 é o primeiro fenômeno pandêmico em era de conectividade global, entretanto, a pandemia provocada pelo Sars-CoV-2, o novo coronavírus, não foi, absolutamente, uma surpresa para muitos pesquisadores.

Tudo começou em dezembro de 2019 quando a Organização Mundial da Saúde recebeu um alerta sobre a existência de vários casos de pneumonia, na província de Hubei, cidade de Wuhan, na República Popular da China. Logo depois, em janeiro de 2020, foi confirmado pelas autoridades chinesas que haviam identificado um novo tipo de coronavírus, não encontrado antes em seres humanos (BUSS, ALCAZAR, GALVAO, 2020, p. 46).

O novo coronavírus espalhou-se rapidamente por todo o planeta, provocando inúmeras mortes ao redor do mundo, notadamente em idosos e cidadãos com doenças preexistentes. Desta feita, em março de 2020 a OMS reconheceu tratar-se de uma pandemia, a qual já estava presente em todos os continentes e ameaçava muitas pessoas de maneira simultânea. (BBC, 2020)

Neste momento, a OMS passou a tomar diversas medidas para contenção do novo coronavírus, explicadas por Valério Mazzuoli (2020, p. 6):

A OMS, baseada em sua normativa, vem tomando diversas medidas para a contenção do novo coronavírus desde o início da pandemia no mundo. Tais determinações (hard law) e recomendações (soft law), provêm do próprio instrumento constitutivo da OMS, concluído em Nova York em 22 de julho de 1946. Há, como se nota, normas determinantes da Organização, provindas de instrumentos de hard law, e disposições recomendatórias, tidas como soft law. 
Ainda, insta salientar que a OMS se refere a agência internacional vinculada a saúde a e assume a condição de organismo internacional. Um de seus documentos principais é o Regulamento Sanitário Internacional o qual visa prevenir e impedir que graves problemas de saúde ultrapassem fronteiras e prejudiquem grande parte da população mundial. Em vigor desde 15 de junho de 2007, o documento possui importância como norma gestora de princípios internacionais de proteção a saúde e, que, em última análise, versa sobre a questão global de direitos humanos (MAZZUOLI, 2020, p. 06).

Desta maneira, depara-se com um cenário de calamidade, em que Organismos Internacionais buscam unificar os países no trabalho de diminuição dos efeitos provocados pela pandemia do novo coronavírus em todo mundo. Entretanto, concomitantemente, observase chefes de Estado adotarem medidas contrárias às recomendações da OMS, os quais trazem novamente à tona a discussão acerca dos limites da soberania estatal e a crise do Estado.

Para Bobbio (1998, p. 1184), “a Soberania, porém, não desapareceu: em épocas normais e tranquilas não é percebida, porque adormecida; em situações excepcionais, em casos limites, ela volta com toda sua força", certamente estamos em um destes momentos excepcionais em que ela retorna com intensidade, o que não poderia ser diferente.

Observa-se o caso específico do Brasil, o qual lidera em segundo colocada o ranking de número de mortes pela pandemia, todavia, o presidente Jair Bolsonaro adotou posições internas diferentes das recomendações da OMS (BBC, 2020), ocasionando questionamentos distintos. Uma linha das indagações seria se o presidente poderia atuar desta forma, contrariando as orientações da OMS, enquanto a outra questionaria por que o presidente deveria seguir as orientações da OMS se o Brasil é um Estado Soberano.

Primeiramente, no caso específico do Brasil, ressalta-se que ele faz parte da OMS, portanto, nas palavras de Mazzuoli "tem o compromisso de cumprir com as suas determinações ou recomendações[...]" que entende tratar-se de medida obrigatória, uma vez que:

[...] além de medida de cooperação internacional, trata-se de obrigação jurídica decorrente da ordem internacional, que visa salvaguardar a saúde humana. Trata-se, em suma, de uma questão mundial de direitos humanos relativa à saúde (OAB, 2020).

Assim, em relação ao primeiro ponto, a não observância das recomendações da OMS por parte de Estados que fazem parte, descredibiliza o organismo internacional que objetiva o 
controle e proteção da saúde mundial. Além de ferir a credibilidade do órgão, questiona-se também o objetivo do Estado participar da própria Organização se, quando solicitado, não segue as recomendações e deliberações, ou seja, a transferência do poder de decisão para entidades supranacionais explicada por Ferrajoli, na prática, não se concretiza. (MAZZUOLI, $\mathrm{OAB}, 2020)$

Nas palavras de Mazzuoli (OAB, 2020), o ato é falho e danoso, e as consequências afetam a toda população:

\begin{abstract}
Seja como for, certo é que, na prática, os Estados - muitas vezes, sem qualquer justificativa plausível - mais desconsideram as decisões dos organismos internacionais competentes que efetivamente as aplicam. À evidência que a conduta estatal não deveria ser dessa forma, por ser a OMS organismo especializado e conhecedor técnico dos problemas sanitários mundiais. Daí a constatação de que o desrespeito às prescrições estabelecidas pela OMS é um ato falho e danoso, não somente para as relações internacionais do País, senão também para a sanidade de todo o planeta, vez que permite o alastramento de pandemia ainda sem cura em todo o mundo. Trata-se, tout court, de ato de irresponsabilidade executiva que está a merecer desobediência por outros agentes públicos - tais governadores dos Estados e prefeitos dos Municípios - que tenham um mínimo de consciência do que está a experimentar o mundo nestes tempos.
\end{abstract}

Desta maneira, observa-se que, embora as recomendações da OMS tenham um caráter vinculante, e que em certo momento histórico a soberania estatal adquiriu um viés de compartilhada, isto porque, parte do poder de decisão estatal foi transferido para instituições supranacionais, ocorre que, ainda não adquirimos a realidade e os efeitos desejáveis no plano fático.

Em relação ao outro questionamento, de que o país seria soberano e por este motivo, não deveria se submeter ao caráter vinculantes das recomendações da OMS, busca-se analisar o item com base no conceito de "constitucionalismo global" proposto por Ferrajoli. Para o referido autor, o período pós segunda guerra mundial com a emergência de documentos internacionais que colocavam a humanidade como referencial unificador do direito, buscaram assegurar um conjunto de direitos mínimos que formam um "constitucionalismo global". Entretanto, para que as cartas e tratados tenham maior adesão e efetividade, e deixem de ocupar a posição de meras declarações retóricas para ocuparem a posição de normas, Ferrajoli acredita que seja necessário a elaboração de um constitucionalismo mundial capaz de oferecer a garantia jurídica faltante (2002, p. 54). 
Ocorre que, o "constitucionalismo global" proposto pelo referido autor ainda não alcançou os efeitos pretendidos no plano fático. Inclusive, ele visualiza que a construção desse constitucionalismo depende, em parte, da atuação de muitos juristas e filósofos, os quais irão contribuir em livrar a doutrina internacionalista da falácia da inefetividade, conforme assevera que:

O direito moderno nada tem de "natural". Ele é, com certeza, como as relações de
força o determinam. Mas também, é mais em geral, como o querem e o constroem
os homens, com suas reivindicações e suas lutas, e inclusive com as elaborações dos
filósofos e juristas. Pelo bem ou pelo mal, o Estado moderno, inclusive aquele
sistema complexo de garantias, que com todos os seus limites é o e estado
democrático de direito, tem sido também o produto da filosofia política e da cultura
jurídica. Portanto, o "como é" e o "como será" o direito - até mesmo o direito
internacional - depende em parte também de nós enquanto pessoas e enquanto
filósofos ou juristas. [...] E, todavia, acreditamos que devemos fugir das atitudes
excessivamente cética e resignadas que compartilham, com as atitudes dos
defensores da ordem desigual existente, a mesma falácia realista: aquela falácia que,
no direito internacional, chama-se de "principio da efetividade" e que remonta,
como já lembramos, a Alberico Gentili e Hugo Grotius. Contra essa falácia, que
prensa o direito ao fato, precisamos recuperar aquela dimensão normativa e
axiológica da ciência jurídica internacional.
constituc É este, portanto o
axiológico de seu trabalho. Isso significa, para a doutrina internacionalista, livrar-se
daquela falácia realista do achatamento do direitos sobre o fato que ainda continua a
pesar sobre ela sob a forma de "princípio de efetividade", e assumir como tarefa
cientifica, além de política, a crítica jurídica dos perfis de invalidade e de caráter
incompleto do direito vigente e planejamento das garantias do direito futuro. (2002,
p. 60-61)

Assim, parte da ineficácia das previsões nos pactos e cartas de Direito Internacional, se devem, de certa maneira, a inércia no comportamento de muitos juristas e filósofos em propiciar e instituir garantias aos instrumentos e órgãos internacionais existentes, isto é, dar efetividade ao conteúdo já disposto em pactos, normas e tratados, para que a doutrina internacionalista consiga se livrar da falácia do principio da efetividade, já esclarecida por Ferrajoli.

Ainda, em relação ao período de pandemia que assola o planeta, constata-se que se trata de uma emergência global e que exige uma resposta global. Sobre o tema, Ferrajoli extrai duas lições que nos obrigam a refletir sobre o futuro. A primeira é sobre a nossa fragilidade e total interdependência. Em que pese a existência de tantos avanços tecnológicos e armamentos, no final, somos todos seres humanos expostos às catástrofes de causas naturais ou meras consequências das ações humanas. A segunda lição diz respeito à necessidade de 
medidas homogêneas a serem adotas no combate a pandemia, a fim de evitar que a divergência nas ações do Estados, em muitos casos completamente inadequadas, acabem favorecendo o contágio e multiplicando os danos para todos (2020, IL MANIFESTO).

Neste ponto, extrai-se exatamente a resposta para as questões acima levantadas. $\mathrm{O}$ ordenamento internacional já possui um Órgão responsável pela proteção e segurança da saúde mundial, a OMS. O caráter global da pandemia foi comprovado pelos países, juntamente com sua alta taxa de transmissão. A pandemia afeta a todos, sem distinção entre ricos e pobres. Desta feita, necessita-se propiciar a oportunidade - já aventada por Ferrajoli anteriormente - de fazer da OMS uma verdadeira instituição de garantia global, isto é, “dotada de poderes e meios econômicos necessários para enfrentar a crise com medidas racionais e adequadas, não condicionadas por contingentes de interesses políticos ou econômicos" para alcançar o objetivo principal, qual seja, a proteção e garantia do direito à vida (2020, IL MANIFESTO).

Alcançar o "constitucionalismo global” não parece distante, uma vez que, os pressupostos de sua existência já estão presentes, sejam os institucionais, como também culturais e sociais. Espera-se que o momento e os efeitos pós pandemia sejam de reavaliação de toda estrutura e funcionamento do Direito Internacional, de modo que o disposto em cartas e tratados aproxime-se da realidade fática em momentos de respostais globais, como o momento em que se vivencia.

O fato é que em um mundo cada vez mais interdependente e conectado que vivencia o aumento da tecnologia e das comunicações, não se pode um Estado se colocar acima das recomendações dos organismos internacionais especializados no assunto, tal como a Organização Mundial da Saúde. Especialmente no caso em que se busca conter o avanço de uma pandemia mundial que está ocasionando milhares de mortes, em tempos de inexistência de certezas nos campos da economia, ciência e saúde.

Entretanto, o conceito de soberania estudado pelos filósofos e juristas não alcança os efeitos pretendidos em certas situações fáticas. Talvez, no momento, vivencia-se uma transição entre os conceitos, como disse Ferrajoli "É provável que se esteja vivendo o 'tempo de transição' entre a modernidade e a era que a substituirá e, em consequência, de superação da Soberania Moderna” (1999, p. 149). De qualquer forma, retroceder não deve ser uma opção. 


\section{CONCLUSÃO}

O ano de 2020 dificilmente será esquecido. Observamos o mundo parar em poucos dias, sem qualquer certeza do dia de amanhã. As dúvidas e questionamentos que antes eram sobre o futuro recente, inundaram os meses e até anos próximos. De repente, poucas coisas são certeza. A maior delas é de que o momento que a humanidade passa merece reflexão sobre o nosso futuro e soluções globais.

A pandemia do novo coronavírus veio para lembrar que como seres humanos estamos extremamente fragilizados. Nossa fragilidade é em relação à natureza, aos desastres naturais, às epidemias e pandemias, e também à própria atuação desenfreada que desempenhamos na natureza e todas as consequências advindas desta atuação. Nesses momentos de impotência, vulnerabilidade, retoma-se o questionamento acerca de muitos temas que até então soavam como "esquecidos".

O órgão responsável pela proteção da saúde mundial recebeu, de maneira vertiginosa, a atenção e a cobrança de todos os países. Em poucos meses, a OMS tornou-se responsável pelas respostas e dúvidas de muitos cidadãos e chefes de Estados, entretanto, quando suas recomendações já não mais atendiam os interesses próprios, a confiança e credibilidade antes depositadas, não pareciam mais existir. Neste cenário de incertezas e medo, ressurge a discussão acerca dos limites da atuação do Estado, especialmente em conflito com decisões de organizações supranacionais, como o caso da OMS.

No artigo, buscou-se entender a crise da soberania inserida especialmente no contexto da pandemia e as novas discussões sobre o tema. O conceito de soberania não condiz mais com o conceito descrito no Estado Absolutista, tampouco do período inaugural pós Segunda Guerra Mundial. Os acontecimentos econômicos demonstram influenciar nas relações internacionais e, por via de consequência, na definição do conceito de soberania. A globalização é importante fator que refletiu no aumento da interdependência estatal, comunicação e tecnologia, resultando na Crise do Estado Moderno que nada mais é do que a crise da própria soberania.

Com o surgimento do novo coronavírus, renovou-se a discussão acerca da necessidade de efetivar o "constitucionalismo global" proposto por Luigi Ferrajoli, para tanto, faz-se necessário dar instituições de garantia jurídica para que os tratados, cartas e convenções cumpram com seus objetivos iniciais e alcancem os efeitos pretendidos. 
A adoção de medidas heterogêneas no combate ao vírus por parte dos Estados enfraquece a resposta mundial e, em muitos casos, favorece o contágio implicando em danos a todos os países. $\mathrm{O}$ momento exige que sejam tomadas atitudes globais para o enfrentamento desses problemas também globais, exige-se a cooperação entre os Estados, a fim de que seja possível construir um futuro com fundamentos comuns e à vista da não repetição de fenômenos como este em que se vivencia.

Desta feita, resta evidente que o mundo pós pandemia não será o mesmo. Os impactos do novo coronavírus serão sentidos em todas as relações, com mudanças que com toda certeza irão além do isolamento social. A transformação deve moldar nossa sociedade pelos próximos anos, resta apenas saber de que forma se dará esta alteração.

Talvez esta tragédia possa finalmente dar lugar a uma consciência geral e necessária com uma atuação conjunta para um bem comum, o que com certeza exigirá instrumentos que efetivem a criação e desenvolvimento do "constitucionalismo global" proposto por Ferrajoli, assim, da "explosão" teremos o nascimento de uma "estrela", configurando o fenômeno da supernova.

\section{REFERÊNCIAS BIBLIOGRÁFICAS}

BBC BRASIL. O que é pandemia e o que muda com declaração da OMS sobre o novo coronavírus. Disponível em: https://www.bbc.com/portuguese/geral-51363153 Acesso em 28 de agosto de 2020.

BBC BRASIL. Coronavírus: os sete erros que põem Brasil na rota do 'lockdown', segundo especialistas. Disponível em: https://www.bbc.com/portuguese/brasil-52551974. Acesso em 02 de setembro de 2020.

BOBBIO, Norberto; MATTEUCCI, Nicola; PASQUINO, Gianfranco. Dicionário de política.

Tradução de Carmen C. Varriale et al. 11. ed. Brasília: UnB, 1998.

BUSS, Paulo M.; ALCAZAR, Santiago; GALVAO, Luiz Augusto. Pandemia pela Covid-19 e multilateralismo: reflexões a meio do caminho. Estud. av., São Paulo, v. 34, n. 99, p. 4564, agosto 2020.

CENCI, Elve Miguel. Globalização, Estado-nação e regimes supranacionais. In: XVI Encontro Preparatório do CONPEDI, 2007, Campos dos Goytacazes. Anais CONPEDI/Campos dos Goytacazes. Florianópolis: Fundação Boiteux, 2007. v. I. Disponível em:http://www.publicadireito.com.br/conpedi/manaus/arquivos/anais/campos/elve_miguel_ce nci.pdf Acesso em: 03 de setembro de 2020 
CENCI, Elve Miguel; MUNIZ, Tânia Lobo. Esplendor e Crise do Constitucionalismo Global. Sequência (Florianópolis), Florianópolis, n. 84, p. 89-108, Abril 2020. Disponível em: http://www.scielo.br/scielo.php?script=sci_arttext\&pid=S2177 Acesso em 29 de agosto de 2020.

CRUZ, Paulo Márcio. Soberania e superação do Estado constitucional moderno. Revista de Direitos e Garantias Fundamentais, n. 2, p. 69-98, 13 ago. 2007.

DALLARI, Dalmo de Abreu. Elementos de Teoria Geral do Estado. 29a ed. São Paulo: Saraiva, 2010.

FARIA, José Eduardo. A globalização econômica e sua arquitetura jurídica (dez tendências do direito contemporâneo). Texto preparado para o Congresso Jurídico Globalización, Riesgo y Medio Ambiente - Universidad de Granada. Disponível em: https://www.academia.edu/43010889/A_globaliza\%C3\%A7\%C3\%A3o_econ\%C3\%B4mica_ e_sua_arquitetura_jur\%C3\%ADdica_dez_tend\%C3\%AAncias_do_direito_contempor\%C3\% A2neo. Acesso em 01 de setembro de 2020.

Direitos humanos e globalização econômica: notas para uma discussão. Estud. av., São Paulo, v. 11, n. 30, 1997.

FERRAJOLI, Luigi. A soberania no mundo moderno. Tradução de Carlo Coccioli e Márcio Lauria Filho. São Paulo: Martins Fontes, 2002.

Il virus mette la globalizzazione con i piedi per terra. Il Manifesto, 17 de março 2020. Disponível em: https://ilmanifesto.it/il-virus-mette-la-globalizzazione-con-i-piedi-perterral. Acesso em 02 de setembro de 2020.

Principia Iuris - Teoría del derecho y de la democracia 2: Teoría de la democracia. Madrid: Trotta, 2013.

Derechos y garantias: la ley del más débil Madrid: Trotta, 4ª edição, 1999.

HABERMAS, Jürgen. A constelação Pós-nacional. São Paulo: Littera Mundi, 2001.

MAZZUOLI, Valerio de Oliveira. As determinações da OMS são vinculantes ao Brasil? In: Conselho Federal da OAB, Notícias, 28 de março 2020. Disponível em: www.oab.org.br/noticia/58018. Acesso em 02 de set. de 2020

Responsabilidade Internacional dos Estados por Epidemias e Pandemias Transnacionais: O Caso da Covid-19 provinda da República Popular da China. Revista de Direito Civil Contemporâneo, vol. 23, 2020,

RAMOS, André de Carvalho. Curso de Direitos Humanos. - 6. ed. - São Paulo: Saraiva Educação, 2019.

SILVA, C. T. L. da; PICININ, G. L. Paz de vestefália e soberania absoluta. In: Revista do 
direito público, Londrina, v.10, n.1, p.127-150, jan./abr.2015.

TRINDADE, Antônio Augusto Cançado. Os Tribunais Internacionais Contemporâneos. Brasília: FUNAG, 2013.

TINOCO, Adriana. O que é uma supernova e como ela se forma? In: Socientífica. 2020. Disponível em: https://socientifica.com.br/o-que-e-uma-supernova-e-como-ela-se-forma/. Acesso em 01 de setembro de 2020. 